\title{
Role of urodynamics in diagnosing tethered cord in spina bifida patients
}

\author{
Pieter Dik*, Sven Nadorp, Johan EH Pruijs, Rob HJM Gooskens, Tom PVM de Jong \\ From 54th Annual Meeting of the Society for Research into Hydrocephalus and Spina Bifida \\ Vancouver, Canada. 7-10 July 2010
}

\section{Background}

The aim of this study was to see how many patients with spina bifida aperta (SBA) developed a clinical significant tethered cord (TC) and how urodynamics influenced this diagnosis.

\section{Materials and methods}

Between 2000 and 2008 approximately 400 SBA patients, under the age of 18 years, were followed. In 70 cases secondary TC was suspected, based on a variety of symptoms: visible back anomalies, loss of strength, changes in lower urinary tract function, increase in scoliosis or a combination of these. Patients had a one day check-up by a multidisciplinary team, consisting of neurologist, orthopedic surgeon, neurosurgeon, physical therapist and urologist. Imaging (MRI) and urodynamic studies were done on the same day. At the end of the day the results were evaluated and a decision was made whether or not to operate for TC.

\section{Results}

26 patients with SBA had untethering or a myelotomy. 18 patients had neurologic changes. 7 of these patients also had changes in urodynamics. None of the 26 patients had urodynamic changes without neurologic deterioration. This is probably because all spina bifida patients were on oxybutynin and CIC. Ten patients had scoliosis and were treated by myelotomy to cure tethering and prevent Chiari complications.

\section{Conclusions}

In a population of 400 SBA patients, 70 patients were seen in a single day check-up for TC suspicion.

\footnotetext{
* Correspondence: p.dik@umcutrecht.nl

Wilhelmina Children's Hospital, Lundlaan 6,Â 3584 EA Utrecht, POBOX 85090, The Netherlands
}

26 patients $(7 \%)$ were treated for symptomatic TC in 8 years time. In this study urodynamics did not contribute to the diagnosis, probably due to the use of antimuscarinics.

Published: 15 December 2010

doi:10.1186/1743-8454-7-S1-S5

Cite this article as: Dik et al:: Role of urodynamics in diagnosing tethered cord in spina bifida patients. Cerebrospinal Fluid Research 2010 7(Suppl 1):S5.
Submit your next manuscript to BioMed Central and take full advantage of:

- Convenient online submission

- Thorough peer review

- No space constraints or color figure charges

- Immediate publication on acceptance

- Inclusion in PubMed, CAS, Scopus and Google Scholar

- Research which is freely available for redistribution

Submit your manuscript at www.biomedcentral.com/submit
() Biomed Central

\section{Ciomed Central}

